\title{
Habitat partitioning and thermal tolerance in a tropical limpet, Cellana grata
}

\author{
Gray A. Williams*, David Morritt** \\ The Swire Institute of Marine Science and Department of Ecology and Biodiversity, The University of Hong Kong, \\ Cape d'Aguilar, Hong Kong
}

\begin{abstract}
Populations of the tropical limpet Cellana grata Gould were studied on exposed shores around Cape d'Aguilar, Hong Kong. C. grata is a high shore species, the zonation pattern of which varies seasonally, shifting downwards in association with increasing summer temperatures. C. grata is a non-homing species and was active (foraging) whilst awash by the tide, moving up and down the shore with the flood and ebb tides, respectively. Limpets moved up to $1 \mathrm{~m}$ in the vertical plane over a tidal cycle. When not foraging limpets took refuge in habitats that reduced the effects of high temperature and desiccation stress. Temperature measurements of individuals and their physical environment showed that the quality of these refuges varied both spatially and temporally. Horizontal rock surfaces were hotter than vertical surfaces; limpet body temperatures and habitat temperatures in refuges (crevices, pool interfaces and east-facing vertical surfaces) were consistantly cooler than adjacent habitats by 3 to $8^{\circ} \mathrm{C}$ and limpet body temperatures were usually $2^{\circ} \mathrm{C}$ warmer than the rock they rested on. Experimental manipulations with specimens restrained $0.5 \mathrm{~m}$ above their normal resting height or on horizontal rock surfaces and prevented from returning to refuges caused desiccation, osmotic stress and, in many cases, death as a consequence of prolonged emersion in these sub-optimal habitats. Individuals on horizontal surfaces lost water more rapidly than those on vertical surfaces and showed higher mortality. C. grata does not adopt many of the behavioural adaptions to reduce heat stress shown by other gastropod species. It does, however, exhibit 'mushrooming' behaviour, lifting its shell from the rock surface, although the exact benefits of this behaviour are unclear. Summer physical extremes may strongly select for limpet activity rhythms entrained by wave splash and the selection of refuges from high temperatures and desiccation when inactive. Variation in the quality of these refuges can lead to selective mortality during very hot periods.
\end{abstract}

KEY WORDS: Limpet · Habitat partitioning - Desiccation - Behaviour - Temperature - Tropical rocky shore

\section{INTRODUCTION}

Physical factors such as temperature and humidity influence the ecology of intertidal organisms (see reviews by Moore 1972, Wolcott 1973, Branch 1981, McMahon 1990). Temperature and desiccation extremes have been proposed to limit the upper limits of species distribution patterns (e.g. barnacles, Connell 1961; limpets, Wolcott 1973; algae, Schonbeck \& Norton 1978). On

\footnotetext{
-E-mail: hrsbwga@hkucc.hku.hk

- Present address: Department of Animal and Plant Sciences, School of Biological Sciences, University of Sheffield, Sheffield S10 2UQ, United Kingdom
}

some shores temperatures can reach lethal levels for intertidal organisms (e.g. Lewis 1954, Frank 1965, Wolcott 1973, Kohn 1993, Williams 1993a, Williams \& Morritt unpubl. data). Species on tropical shores often experience high temperatures $\left(>50^{\circ} \mathrm{C}\right.$; Williams 1994) with associated thermal and desiccation stresses (Moore 1972) and numerous species show adaptations to reduce these stresses by hiding in refuges (cracks and crevices), sealing their shells with mucus and positioning their shells to minimize exposure to insolation (see Garrity 1984 for review). Habitat choice has been shown to play a vital role in the survival of many species (Davies 1969, Wolcott 1973, Leviten \& Kohn 1980). To ensure prolonged survival, sessile species have to settle in areas of the shore that will provide shelter from 
physical extremes (Raimondi 1990) and if they do not they are susceptible to 'high shore kills' (Hawkins \& Hartnoll 1985, Liu \& Morton 1994). If prevented from returning to refuges after foraging, gastropods desiccate and die (see Garrity 1984). Physical constraints on individual species can also have indirect effects on community structure; for example, algae have spatial escapes in areas that are beyond the foraging range that Nerita scabricosta can achieve from its refuges during a tidal cycle (Garrity \& Levings 1981).

Limpets are often the dominant mobile herbivores on temperate and tropical shores (Branch 1981). Different species exhibit a variety of behavioural rhythms, foraging whilst emersed at night and daytime, whilst awash or whilst submerged (see Branch 1981, Little 1989). Many species home to specific sites on the rock surfaces whilst others select suitable non-permanent resting sites. The choice of resting site and the period of activity have been interpreted as being imposed by physical limitations on the physiological tolerances of the species, although shelter from predation and access to food supply are also important factors (see review by Little 1989). If the limpet should settle in an unsuitable habitat, or move at the wrong time of the day, then physical factors may exceed the tolerance limits of the species resulting in physiological stress and often mortality (see Wolcott 1973 for discussion). Numerous workers have investigated the physiological tolerances of limpets by measuring limpet body temperature, corresponding water loss and ionic concentrations of the haemolymph or extravisceral water (e.g. Segal \& Dehnel 1962, Davies 1970, Wolcott 1973, Verderber et al. 1983, Lowell 1984, Branch \& Cherry 1985). Limpets have been shown to be remarkably resilient to such extremes (see discussion by Wolcott 1973) and their physiological limits measured in the laboratory are rarely exceeded under field conditions.

In this study we investigate spatial and temporal variation in the thermal relationship between a tropical limpet, Cellana grata Gould, and its physical environment. C. grata is a high shore species which sporadically suffers high mortality during hot, calm weather periods in Hong Kong (Williams 1993b). Differences between habitat temperatures and limpet body temperature were monitored during emersion periods and these physical parameters are related to the behaviour exhibited by this species to minimize physical stress. We test the hypothesis that the observed behaviour patterns and habitat choice play an important role in reducing temperature stress in C. grata.

\section{MATERIALS AND METHODS}

Sites and timing. Populations of Cellana grata were studied at 10 exposed shore sites in the vicinity of Cape

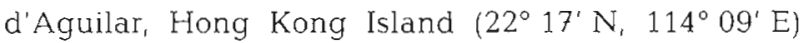
between November 1992 and August 1993. Most sites were of sloping igneous bedrock and had numerous cracks and crevices. Four sites were studied more extensively; 3 were at Cape d'Aguilar (Cape Slope, a large sloping area of granodiorite which had a southerly aspect, Cape Wall, a vertical rock face with a westerly aspect and Cape Ledge, a vertical wall which opens onto a horizontal platform in the mid-high shore). The fourth site was at nearby Big Wave Bay. Hong Kong experiences mixed semidiurnal spring tides with a range of $-2.5 \mathrm{~m}$ and diurnal neap tides (Hong Kong Royal Observatory). At each study site $25 \mathrm{~cm}$ height increments were marked from 1.0 to $3.0 \mathrm{~m}$ above Chart Datum (CD) (see Williams 1994). At the Cape Wall site the vertical distribution of limpets could be measured directly with reference to height markers on the $180^{\circ}$ rock face.

Distribution and abundance. To assess the vertical distribution of Cellana grata and associated organisms, 10 random quadrats were scored at each $25 \mathrm{~cm}$ height interval. Individuals were measured using vernier calipers $( \pm 0.1 \mathrm{~mm})$. Small limpets $(<5 \mathrm{~mm})$ were often difficult to identify in the field and were not included in population histograms. Transect surveys were conducted in November (Big Wave Bay), March (Cape Slope and Big Wave Bay), June, July and August (Cape sites). The dates of samples were variable due to tidal conditions and time constraints.

Biofilm abundance was assessed at selected sites by extracting chlorophyll a using hot methanol (Hill \& Hawkins 1990) from rock chips taken randomly at the heights at which Cellana grata was found. In March 1993, rock chips $(n=6)$ were taken from 3 to 4 heights at Cape Slope and in July 1993 chips ( $n=5$ to 10) were taken at $25 \mathrm{~cm}$ intervals from the heights occupied by limpets and also heights above and below this zone at the Cape Slope and Wall sites.

Diurnal rhythm of behaviour. Qualitative notes were made during visits to the field at different stages of the tidal cycle, weather conditions and times of day. A quantitative survey of movement patterns was made on 6-7 July 1993 when the activity of 30 marked limpets at both the Cape Slope and Cape Wall sites was recorded. Limpets were numbered with Tipp-Ex (Tipp-Ex GmbH \& Co. KG, Frankfurt am Main, Germany) and observed every hour over a $28 \mathrm{~h}$ period. Nocturnal observations were carried out using red light (cf. Little \& Stirling 1985). Individuals were scored as active if they moved within $15 \mathrm{~s}$ of abservation. The highest reach of the waves was recorded and the lowest point of the backwash was also noted; these limits defined the area which was 'awash'. At the Cape Wall site the position of the limpets in the vertical plane was also measured $( \pm 1 \mathrm{~cm})$. 
Measurement of thermal characteristics. Limpet and environmental temperatures were measured using Omega K-type (Teflon insulated) thermocouples (diameter $0.25 \mathrm{~mm}$ ) connected to a portable 40-channel Omega M5000 datalogger (Omega, USA). The following variables were measured during daytime emersion periods:

(1) Rock surface temperature: This was defined as the surface of the rock exposed to wind and insolation and was measured by affixing the thermocouple wire to the rock using Blue-Tac (Bostick, Ltd) so that the unshaded tip of the thermocouple was in direct contact with the rock surface.

(2) Air temperature: Measured using non-shaded probes positioned between 2.0 and $4.0 \mathrm{~cm}$ above the rock surface

(3) Sea water/pool temperature: Probe immersed in the appropriate body of water.

(4) Limpet temperatures: Limpet temperatures were measured using either a thermocouple inserted onto the foot by pushing between the shell and the rock surface (after Wolcott 1973) or a thermocouple positioned in contact with the body viscera through a hole drilled just posterior to the apex of the shell and fixed with dental restorative filling (GC Fuji II Glass). Preliminary investigations showed no difference in these 2 techniques nor in the temperature of different sized individuals (ANOVA; $\mathrm{p}<0.05$ ). Measurements of foot temperature were adopted as the common mode of assessing limpet body temperatures as this method was less stressful to the specimen and also more simple to perform. There was no evidence (100\% recapture of marked individuals) that inserting a probe under the shell of limpets had any negative post-implant effect on the limpets.

Sample sizes varied because habitats, on occasion, did not provide enough limpets in accessible positions, limpets rejected probes or not enough limpets were present. As a result some comparisons (where $n<3$ ) are presented graphically but not statistically analyzed, as are data for air temperatures. As individual specimens were monitored at regular intervals during the day, statistical analysis of diurnal changes is inappropriate because readings from individuals are not independent. Diurnal changes are thus presented graphically and statistical analysis (usually some model of ANOVA) was carried out at the hottest point of the day, or when sample sizes were maximal. Prior to ANOVA, data were checked for homogeneity of variances and normality and where these assumptions were violated, appropriate transformations were made. Significant differences were further investigated using Student-Newman-Keuls (SNK) tests (Zar 1984).

Comparison of sites and habitats. The distribution and density of limpets and the corresponding habitat temperatures were quantitatively assessed at 10 sites on the Cape d'Aguilar peninsula on 16 July 1993 during daytime emersion. Limpets were found in specific habitats: crevices, vertical walls, the interface between pools and exposed rock surfaces. Substrata designated as cracks or crevices (>2 cm depth), vertical walls $\left(>130^{\circ}\right)$, shaded overhangs (substrata not exposed to direct insolation during the middle part of the day) and the interface between the rock surface and pool water were defined as 'limpet refuges' because they were occupied by inactive individuals. Horizontal rock surfaces, high-shore vertical surfaces and large crevices/ sloping surfaces which received direct insolation during the hottest part of the day were rarely occupied and were considered non-preferred habitats. Temperature variation between habitats was monitored at different sites and on different days. The basic design was to measure limpet body temperatures and the rock temperatures in definable refuge habitats and in immediately adjacent habitats (within $25 \mathrm{~cm}$ ), e.g. comparisons were made between vertical areas with limpets and adjacent horizontal surfaces at the same tidal height. The following comparisons were made:

Different vertical heights: On 16 July 1993, 4 probes were placed at each of five $25 \mathrm{~cm}$ interval tidal heights (from $2.50 \mathrm{~m}$ down to $1.50 \mathrm{~m}$ above $\mathrm{CD}$ ) thereby including the levels at which limpets actively foraged and to which they retreated during emersion at the Cape Wall and Cape Slope sites.

Refuges vs adjacent habitats: Temperatures were recorded where limpets were present in refuges and in immediately adjacent habitats. Specific comparisons were made between different vertical heights in one experimental area and between horizontal surfaces and vertical surfaces in another area. The position of the probes in either habitat was never more than $25 \mathrm{~cm}$ apart for each comparison.

Temperature differences between different refuges: Measurements of limpet body temperatures were made in different types of refuges (vertical surfaces in crevices, horizontal surfaces in crevices and pool water/rock surface interfaces) on 15 July 1993 at Cape Slope. Thermal relationships at the pool water/rock interface were further investigated on 4 August 1993 on the east shore of the Cape d'Aguilar peninsula.

Aspect: Rock temperatures were measured on the east, south, west and north facing slopes of a large $(\sim 2 \times 2 \mathrm{~m})$ boulder on the east coast of the Cape d'Aguilar peninsula. Body temperatures of limpets, which were found only on the east face, were also recorded.

Experimental manipulation of limpet behaviour. Actively foraging individuals were prevented from retreating with the ebbing tide by wire mesh barriers (mesh size $=5 \times 5 \mathrm{~mm}$ ) screwed into previously drilled holes. Limpets were restrained at $-2.25 \mathrm{~m}$ above $\mathrm{CD}$ on 
horizontal surfaces at the Cape Ledge site on 20 and 21 July 1993 and on vertical surfaces at the same height at the Cape Wall site on 20 July 1993. As the rock surface dried out, limpets settled and abandoned attempts to move downshore, allowing removal of the mesh barriers. Thermocouples were inserted into individuals retained at high shore and into those which had been allowed to return to a low shore 'normal' height $(\approx 1.75 \mathrm{~m}$ above $C D$ ). No procedural control was applied to the limpets allowed to return to their normal shore level. To try and minimize disturbance effects, however, limpets not directly in contact with the barrier were used for experimentation. At the Cape Wall site, 38 specimens were restrained and 6 were monitored at each height on 20 July. Post-manipulation survival was monitored in all the high shore limpets and a control set of lower shore limpets. At the Cape Ledge site only 4 individuals were trapped on 20 July, but 24 on 21 July 1993. All 4 high shore limpets were monitored on 20 July and 7 at each height on 21 July. All restrained individuals died (defined as being unable to cling to the rock when pushed with a pencil eraser, after Garrity 1984; upon examination these specimens had little or no pallial water, the mantle tissue was retracted and there was no retraction response when the cephalic tentacles were stimulated) on 20 July. On 21 July mortality was also recorded and haemolymph samples were taken directly from the heart of recently dead individuals. At the end of the experimental period, haemolymph samples were taken from 7 surviving high shore, restrained limpets and 7 low shore limpets. Haemolymph samples were stored at $4^{\circ} \mathrm{C}$ and the osmolality (mOsm $\mathrm{kg}^{-1}$ water) of $10 \mu \mathrm{l}$ subsamples measured using a Wescor 5500 Vapour Pressure Osmometer within 24 h of collection. Prior to haemolymph sampling all limpets were weighed to the nearest $0.001 \mathrm{~g}$ and after sampling dried to a constant weight and re-weighed to determine percentage water content. Post-manipulation survival of the remaining high shore and a control low shore group was also monitored.

Desiccation experiments. Limpets in the size ranges 22 to $26 \mathrm{~mm}$ (= small) and 29 to $33 \mathrm{~mm}$ (= large) were collected on 14 July 1993 and returned to the laboratory where they were maintained on a normal tidal cycle for $24 \mathrm{~h}$ prior to experimentation. From each size class 30 specimens were removed from the tidal tank and placed on ceramic tiles, used to simulate rock surfaces whilst allowing weighing with minimal disturbance to the specimen. These tiles had temperature values in the same range as those for the ambient rock surfaces in the field ( $t$-test; $p<0.05$ ). Limpets on tiles were placed in plastic trays and covered with sea water for $15 \mathrm{~min}$ to allow the limpets to replenish any lost mantle water. They were then removed, air dried for 15 min by placing the tiles on paper towelling, weighed and placed on the shore at $2.0 \mathrm{~m}$ above $\mathrm{CD}$ on a horizontal rock surface. A control set of tiles without limpets also underwent the same procedure to allow correction for hydration/drying rates of the tiles. Individuals were weighed every hour initially, then every $2 \mathrm{~h}$ until the onset of mortality, after which hourly weighing was resumed. Dead individuals were wet weighed and then dried to constant weight at $60^{\circ} \mathrm{C}$.

A similar experiment was performed on 27 July 1993 using the 22 to $26 \mathrm{~mm}$ size class of limpets, except individuals were placed in a vertical orientation by fixing Velcro strips to the vertical rock face and the underside of the tiles. A set of control tiles and 30 experimental limpets were used and weighed hourly.

\section{RESULTS}

\section{Distribution and abundance}

Cellana grata was found in the eulittoral zone on all the shores studied (Fig. 1). When stationary (i.e. not foraging) it was associated with barnacles Tetraclita squamosa Pilsbry and scattered littorinids Nodilittorina radiata (Eydoux and Souleyet), in cracks and crevices or on vertical rock surfaces. Lower on the shore Cellana toreuma Reeve, Liolophura (= Acanthopleura) japonica (Lischke) and Patelloidea saccharina L. dominated with occasional Siphonaria spp. The encrusting cyanobacterium Kyrtuthrix maculans Umezaki was found slightly above the $C$. grata zone and scattered crusts of the algae Hildenbrandia rubra (Sommerfelt) Meneghini and Ralfsia spp. were found in crevices below. The zonation of C. grata varied with site and with time. On more exposed shores (e.g. Big Wave Bay) the limpet dominated relatively higher shore levels (+3.5 $\mathrm{m} \mathrm{CD})$ than at more sheltered sites (e.g. Cape sites; +2.0 to $2.5 \mathrm{~m} \mathrm{CD}$ ). With the onset of summer, however, populations moved lower down the shore, the 'preferred height' decreasing by as much as $1 \mathrm{~m}$ (Fig. 1). There was a large variation in the numbers found, reflecting the clumped distribution of this species in refuges when stationary.

The population structure of Cellana grata was dominated by 2 identifiable cohorts (Fig. 2). The dominance of the main cohorts differed among sites as did the size of the individuals. Big Wave Bay was dominated by numerous limpets in the first cohort which were in the size range 7 to $15 \mathrm{~mm}$. The smaller cohort at the Cape sites was larger in mean size than that at Big Wave Bay (between 11 and $20 \mathrm{~mm}$ ) although it was also the dominant cohort.

The abundance of biofilm, as assessed using chlorophyll a concentration, was very variable and ranged between 0.5 and $2.7 \mu \mathrm{g} \mathrm{cm}^{-2}$ (Fig. 3). There was no 


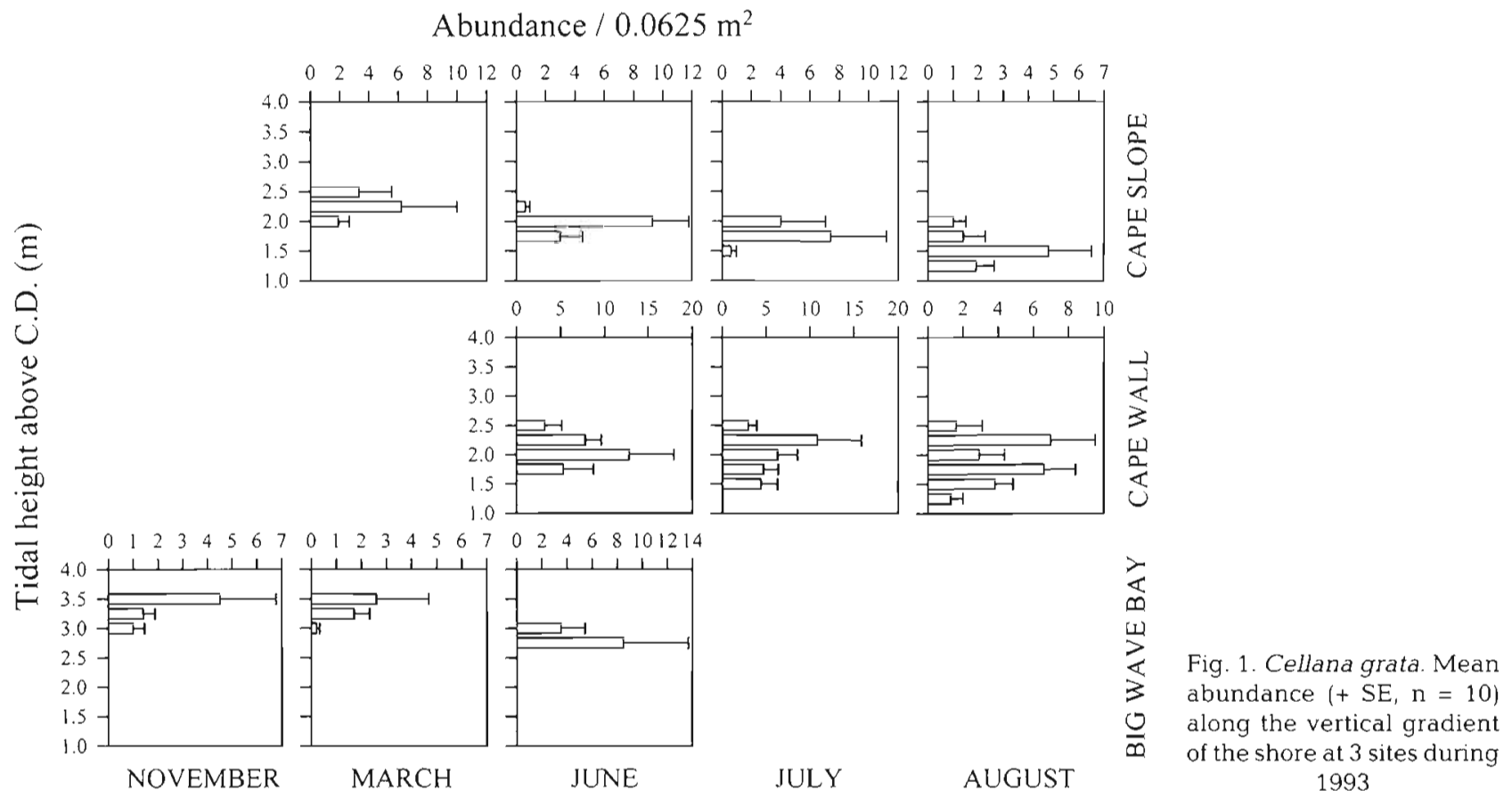

consistent relationship between vertical height and biofilm abundance. At the Cape Slope sites in March and August concentration increased from mid shore to high shore whilst for the Cape Wall the opposite trend was evident.

\section{Diurnal rhythm of behaviour}

Tidal heights throughout this study were calculated from predicted tide levels (Hong Kong Royal Observa- tory). On calm days these matched the observed conditions and the tidal heights used on the shore were in good agreement with predicted levels. On windy days, however, wave action can cause the wetting of the entire shore. During Typhoon Koryn (27 June 1993), for example, the shores were effectively permanently drenched by waves for $3 \mathrm{~d}$.

Cellana grata was active only whilst awash and was never normally totally immersed unless the tide extended higher than the substrate (Fig. 4A and Williams \& Morritt unpubl. obs.). When the popula-
BIG WAVE BAY
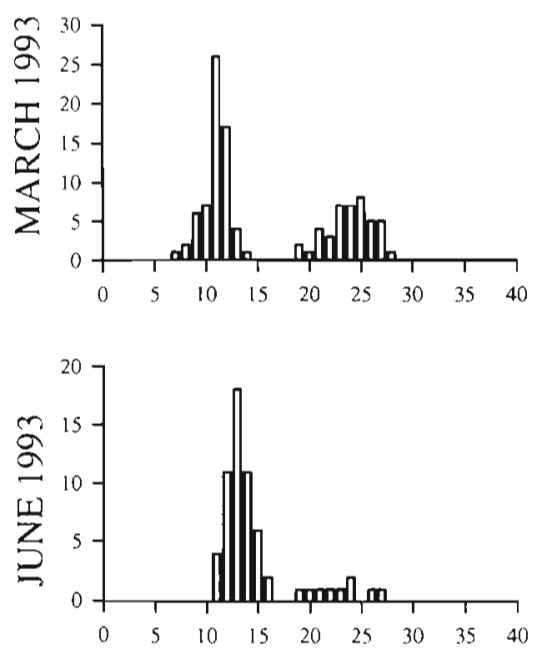

CAPE SLOPE
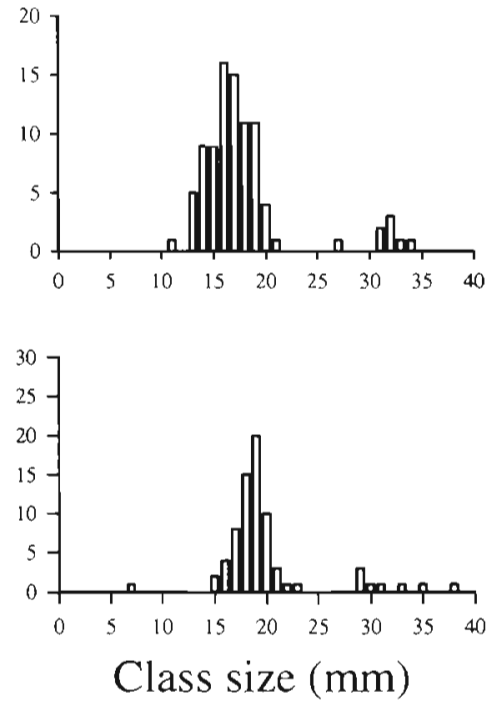

CAPE WALL

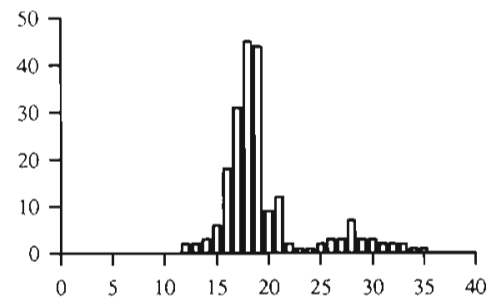

Fig. 2. Cellana grata. Population sizefrequency histograms for populations from 3 sites in 1993 


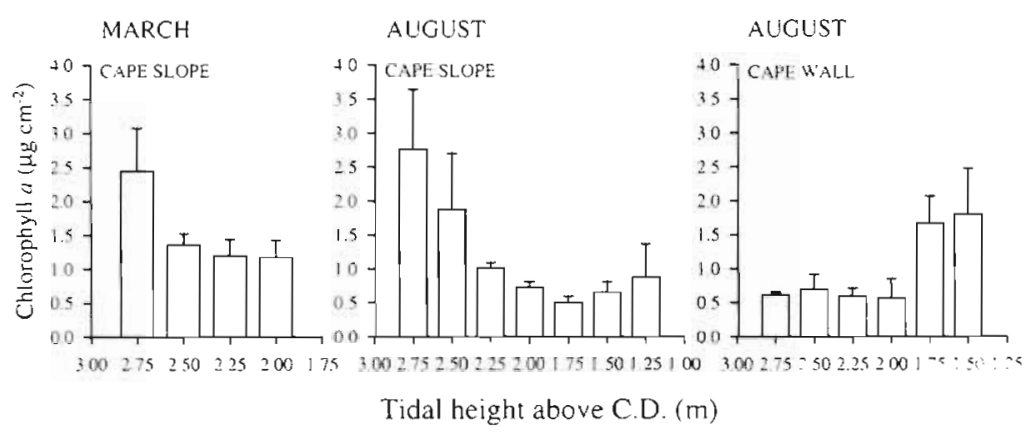

Fig. 3. Biofilm abundance (as assessed by chlorophyll $a$, mean + SD) for Cape Slope and Wall sites in March and August 1993 ( $n=6$ for March and $n=5 / 10$ for August) tests could resolve no further differences between heights; the Site $\times$ Height interaction term was not significant). At the Cape Wall site the hottest level was $1.50 \mathrm{~m}$ above CD (the lowest level), whereas at the Cape Slope site it was the highest area of shore at $2.50 \mathrm{~m}$ above CD Differences between the heights were most clearly seen at the hottest parts of the day $\left(-5^{\circ} \mathrm{C}\right.$, between $12: 00$ and $15: 00$ h) and after this period the differences between the heights were less pronounced.

Refuges vs adjacent habitats. In all cases rock temperatures and limpet body temperatures were cooler, by 4 to $10^{\circ} \mathrm{C}$

tion was washed by waves activity immediately started and the whole population became active, moving upshore with the wave splash (Fig. 4B). Activity decreased at high tide but then increased again as the tide ebbed (Fig. 4A) and individuals returned to the zone that they occupied when stationary (Fig. 4B). On average individuals moved $1.0 \mathrm{~m}$ in the vertical plane on foraging trips which almost exactly coincided with the reach of the waves (Fig. 4B). On stormy days C. grata has been observed to be active for greater than $8 \mathrm{~h}$ whilst awash by waves (Williams \& Morritt unpubl. data). During the period of the study no other activity pattern was recorded.

\section{Comparison of sites and microhabitats}

Cellana grata was found in very specific habitats when stationary (Table 1). Limpets were rarely found on horizontal rock surfaces exposed to direct insolation and were most abundant on east facing surfaces or in shaded overhangs or crevices of rock where they attained high densities. Scattered individuals were found at the interface between pool water and the dry rock surface. Individuals of C. grata that did not find shelter in these refuges and were found on horizontal rock surfaces showed signs of stress ('mushrooming', lifting up their shells) and were often dead by the end of an emersion period (Williams \& Morritt unpubl. data) coinciding with high temperatures.

Vertical height differences. Vertical slopes (with a SW aspect) at the Cape Wall site remained much cooler (approximately $4^{\circ} \mathrm{C}$ ) than horizontal surfaces (with a slight $S$ aspect) on the Cape Slope (Fig. 5; 2-way ANOVA, Site: $1,30 \mathrm{df}_{;} F=18.48 ; \mathrm{p}<0.001$ ). There was, however, no clear relationship between temperature and vertical height on the shore (Fig. 5; 2way ANOVA, Height: $4,30 \mathrm{df}_{i} F=3.71$; $\mathrm{p}=0.014$; SNK in refuge habitats as compared to immediately adjacent habitats (Fig. 6, Table 2). Limpet body temperatures were approximately $2^{\circ} \mathrm{C}$ higher than their substrate. Horizontal rock habitats were found to be hotter than vertical habitats (Fig. 6A, B).
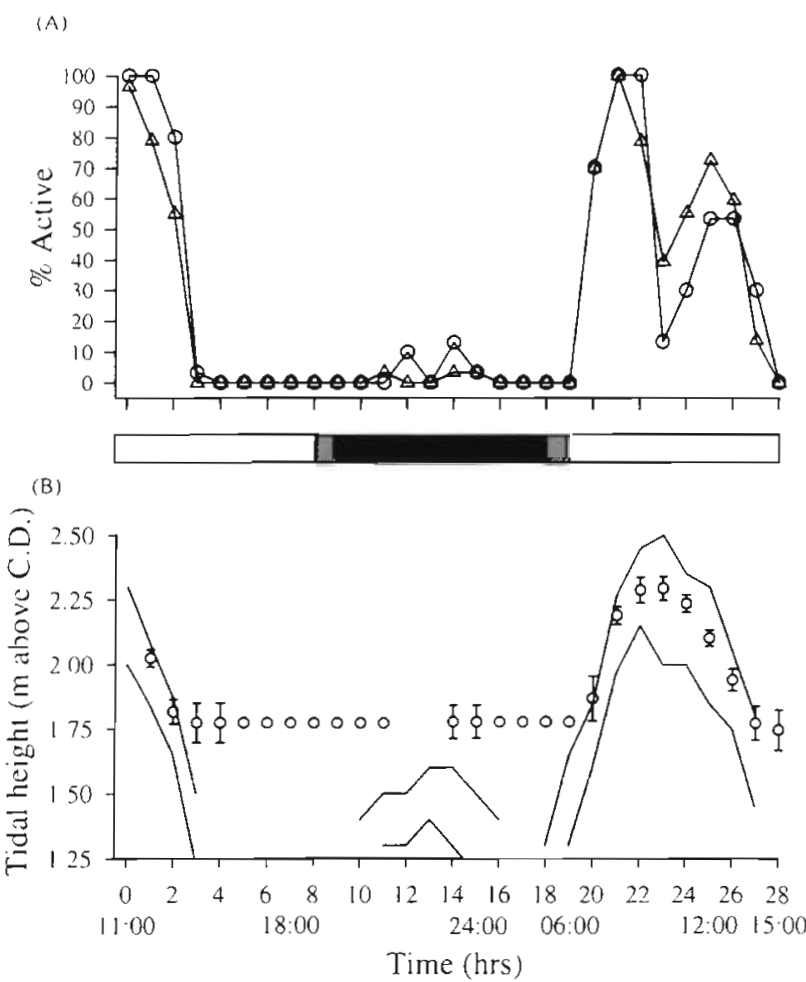

Fig. 4. Cellana grata. (A) Percentage activity of 2 populations (o: Cape Wall; $\Delta$. Cape Slope; $n=30$ for each site) recorded over a $28 \mathrm{~h}$ period. (B) Mean vertical position ( $\pm \mathrm{SD}$ ) for limpets at the Cape Wall site relative to the state of the tide. Continuous lines represent the highest and lowest recorded reach of the waves (i.e. the 'awash' period of the tide). Horizontal bar represents light conditions; dusk and dawn are stippled 
Table 1. Cellana grata. Qualitative survey of limpet distribution and associated habitats on 16 July 1993 between $13: 40$ and 14:30 h at Cape d'Aguilar, Hong Kong

\begin{tabular}{|c|c|c|c|c|c|c|}
\hline \multirow[t]{3}{*}{ Site } & \multirow[t]{3}{*}{ Description of site } & \multirow[t]{3}{*}{ Limpet distribution } & \multirow{3}{*}{$\begin{array}{l}\text { Limpet density } \\
(\text { mean } \pm \text { SD }) \\
(25 \times 25 \mathrm{~cm}, \mathrm{n}=3)\end{array}$} & \multicolumn{3}{|c|}{ Temperatures measured $\left({ }^{\circ} \mathrm{C}\right.$, mean $\left.\pm \mathrm{SD}, \mathrm{n}=3\right)$} \\
\hline & & & & \multicolumn{2}{|c|}{ Exposed to sun } & \multirow{2}{*}{$\begin{array}{l}\text { Shaded } \\
\text { Vertical }\end{array}$} \\
\hline & & & & Horizontal & Vertical & \\
\hline 1 & $\begin{array}{l}\text { Vertical rock; } \\
\text { south facing }\end{array}$ & Shaded underhang & $12 \pm 8.8$ & - & $40.5 \pm 0.15$ & $34.8 \pm 0.69$ \\
\hline 2 & $\begin{array}{l}\text { Vertical rock, } \\
\text { south facing }\end{array}$ & Shaded underhang & $4.7 \pm 4.16$ & - & $43.5 \pm 1.17$ & $34.7 \pm 0.2$ \\
\hline 3 & $\begin{array}{l}\text { Rock slab; shaded } \\
\text { on east face }\end{array}$ & $\begin{array}{l}\text { Limpets on east } \\
\text { face only }\end{array}$ & $57.7 \pm 20.5$ & $42.8 \pm 1.35$ & $39.9 \pm 1.5$ & $33.1 \pm 0.67$ \\
\hline 4 & $\begin{array}{l}\text { Crevices/underhangs } \\
\text { SE facing }\end{array}$ & $\begin{array}{l}\text { Shaded vertical } \\
\text { surfaces only }\end{array}$ & $29.6 \pm 11.5$ & $41.3 \pm 0.56$ & - & $33.0 \pm 0.46$ \\
\hline 5 & $\begin{array}{l}\text { Adjacent to Site } 4 \\
\text { NW facing }\end{array}$ & None present & - & $43.1 \pm 1.3$ & $40.8 \pm 1.45$ & - \\
\hline 6 & South facing rock & $\begin{array}{l}\text { Concentrated on } \\
\text { underhangs }\end{array}$ & $46.3 \pm 16.1$ & - & $41.4 \pm 2.11$ & $33.9 \pm 0.66$ \\
\hline 7 & West facing rock & $\begin{array}{l}\text { Shaded south facing } \\
\text { underhang }\end{array}$ & $66(n=1)$ & $36.8 \pm 1.00$ & - & $32.0 \pm 0.15$ \\
\hline 8 & East facing rock & On vertical surfaces & $21.7 \pm 11.0$ & $41.7 \pm 1.00$ & - & $34.7 \pm 0.45$ \\
\hline 9 & $\begin{array}{l}\text { Pool/rock } \\
\text { interface }\end{array}$ & $\begin{array}{l}\text { In a band at } \\
\text { water's edge }\end{array}$ & $\begin{array}{l}\text { Scattered } \\
\text { individuals }\end{array}$ & $40.37 \pm 0.15$ & Pool water & $32.3(n=1)$ \\
\hline 10 & $\begin{array}{l}\text { Pool/rock } \\
\text { interface }\end{array}$ & At water's edge & $\begin{array}{c}\text { Scattered } \\
\text { individuals }\end{array}$ & $39.9 \pm 0.53$ & Pool water & $35.8 \pm 0.32$ \\
\hline
\end{tabular}

Variation in temperature in different refuges. Cellana grata on horizontal surfaces in refuges were always hotter $\left(-3^{\circ} \mathrm{C}\right)$ than on vertical surfaces in refuges (Fig. $7 \mathrm{~A}$, Table 3 ). Vertical surfaces facing west were much hotter $\left(8^{\circ} \mathrm{C}\right)$ than those adopted by the majority of C. grata which were east facing (Fig. 7C). Limpets at rock pool interfaces were consistently cooler $\left(\sim 2^{\circ} \mathrm{C}\right)$ than limpets slightly higher and not in contact with pool water (Figs. 7B, C \& 8, Table 4). In most cases the limpet body temperature was again higher than the corresponding rock temperature (Table 3).

Aspect. Rock temperature varied with aspect and with time (Fig. 9). West facing slopes heated up during the day to over $44^{\circ} \mathrm{C}$ whereas north and east facing surfaces cooled down to $31-32^{\circ} \mathrm{C}$ during the day. Limpets were found only on east facing surfaces where their body temperatures were slightly higher than the rock substrate (Fig. 9).
Fig. 5. Comparison of mean rock temperatures $(n=5)$ at 5 heights at Cape Slope and Cape Wall over a $5 \mathrm{~h}$ period on 16 July 1993. Symbols represent different tidal heights
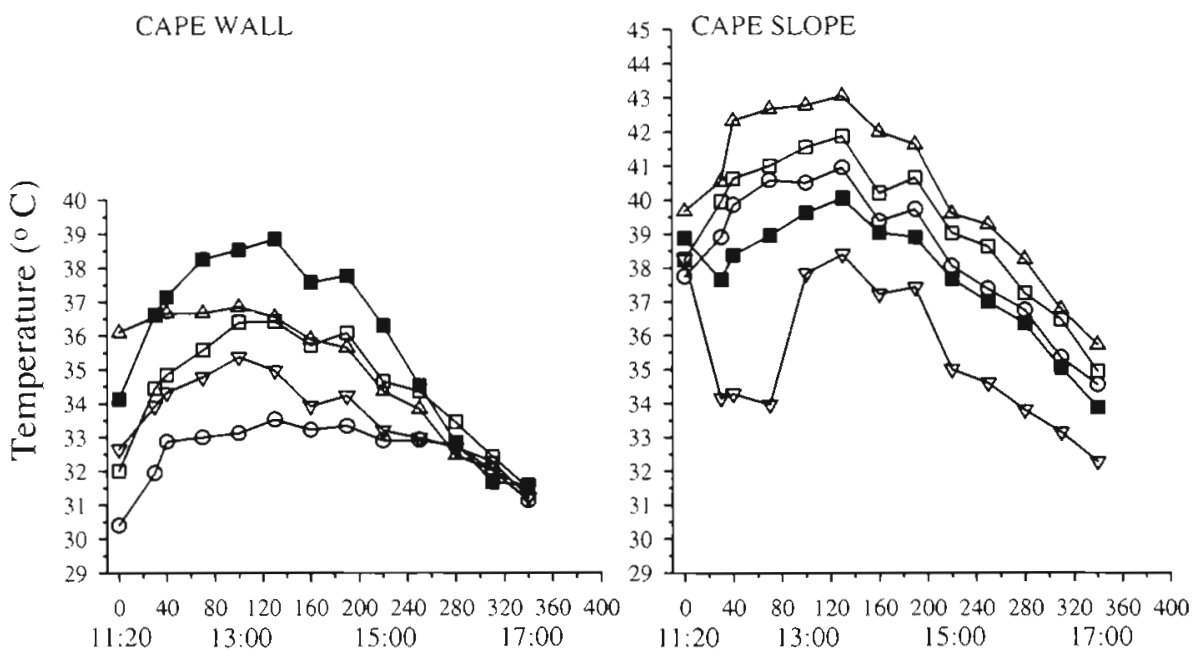

Time (min)

Tidal heights

$\Delta 2.50 \mathrm{~m}$

○ $2.25 \mathrm{~m}$
$1.75 \mathrm{~m}$

- $1.50 \mathrm{~m}$ 


\section{Experimental manipulation of limpet refuges/retreats}

Limpets restrained above their normal resting zone experienced significantly higher temperatures, between 1.5 and $3.5^{\circ} \mathrm{C}$, than those that returned normally to refuges (Fig. 10, Table 5). Limpets on horizontal surfaces experienced far higher temperatures than those on vertical surfaces and at the end of the emersion period $40 \%$ were dead (Fig. 11). Differences between restrained and free-moving limpets and habitat temperatures were reduced on vertical surfaces. Haemolymph osmolality was significantly higher (Table 6; Kruskal-Wallis tests, $H=15.38,2 \mathrm{df}, \mathrm{p}<0.001$ ) in limpets which died as compared to those which were restrained but had survived the emersion period and free-moving individuals, which returned to their normal level. There was no obvious post-experiment effect on mortality as a result of restraining individuals at high shore (Table 6). Dead specimens were smaller and had lost proportionally more water than those surviving (Table 6).

\section{Desiccation experiments}

Both large and small limpets lost water rapidly on tiles on horizontal substrates (Fig 12). Smaller limpets lost water more rapidly than large ones (significant differences after $3 \mathrm{~h}$, Mann-Whitney test: $U=733, p=0.007$; and after $4 \mathrm{~h}: U=324, \mathrm{p}=0.001$ ) and all these individuals lost approximately $30 \%$ of their water and had died after 5 h exposure. Specimens which were situated in a

Table 3. Cellana grata. Two-way ANOVA to compare rock and limpet foot temperatures in different habitats (horizontal and vertical refuges at $2 \mathrm{~m}$ above $\mathrm{CD} ; \mathrm{n}=5$ ) at Cape Slope on 15 July 1993 (recordings from 14:05 h). (Comparisons of limpet and habitat temperatures from pool water/rock interfaces were not made due to the small sample size, but these are graphically displayed in Fig. 7.) "Significant values

\begin{tabular}{|c|c|c|c|c|}
\hline Factor & $d f$ & MS & $F$ & $\mathrm{p}$ \\
\hline Habitat & 1 & 47.66 & 15.08 & $0.001^{\circ}$ \\
\hline Rock vs limpet & 1 & 15.89 & 5.03 & $0.04^{\circ}$ \\
\hline Interaction & 1 & 0.07 & 0.02 & 0.88 \\
\hline Error & 15 & 3.16 & & \\
\hline \multicolumn{5}{|c|}{$\begin{array}{l}\text { Vertical rock temperatures < Horizontal rock temperatures } \\
36.32^{\circ} \mathrm{C} \\
39.50^{\circ} \mathrm{C}\end{array}$} \\
\hline \multicolumn{2}{|c|}{$\begin{array}{l}\text { Rock temperatures } \\
36.99^{\circ} \mathrm{C}\end{array}$} & \multicolumn{3}{|c|}{$\begin{array}{l}\text { Limpet body temperatures } \\
\qquad 38.83^{\circ} \mathrm{C}\end{array}$} \\
\hline
\end{tabular}

\section{DISCUSSION}

\section{Vertical distribution and abundance}

The tidal range occupied by Cellana grata varied among sites, probably as a function of the degree of wave exposure experienced at those sites. For example, at Big Wave Bay, the more exposed site, C. grata was found in greater abundance at $+3.5 \mathrm{~m}$ as compared to $+2.5 \mathrm{~m}$ at the Cape d'Aguilar sites. In a previous study (Liu 1994) C. grata were recorded along the entire vertical range of the shore; this is extremely unusual and in disagreement with other workers who rarely recorded C. grata below $+1.0 \mathrm{~m}$ on any shore studied (Williams 1993b, S. Kaehler \& K. Harper unpubl. data, Williams \& Morritt unpubl. data). C. grata lives for up to $3 \mathrm{yr}$ (Liu 1994) and 2 principal cohorts were found at the sites studied. There was variation in the size and the dominance of the different year classes at different sites, suggesting inter-site variability in population survival and/or recruitment. C. grata was found associated with sparse cover of the barnacle Tetraclita squamosa and below a band of the cyanobacterium Kyrtuthrix maculans. Lower on the 
Table 4. Cellana grata. One-way ANOVA to compare limpet and rock temperatures for individuals on a pool water/rock interface on 4 August 1993 (recordings from 15:46 h). Measurements were made of limpets ( $\mathrm{n}$ $=5$ ) and rock temperatures on the interface $(n=4)$ and pool temperatures $(n=4)$ and for limpets and rock temperatures $15 \mathrm{~cm}$ above this interface ( $\mathrm{n}=3$ and 4 respectively). Data were log transformed to homogenize variances. 'Significant value

\begin{tabular}{|lrllc|}
\hline Factor & df & MS & F & p \\
\hline Treatment & 4 & 0.0176 & 30.10 & $<0.001^{\circ}$ \\
Error & 15 & 0.00058 & & \\
& & & & \\
SNK tests & & & & \\
Pool $<$ Limpets on interface & $<$ Rock & High limpets & $<$ High rock \\
$34.2^{\circ} \mathrm{C}$ & $36.36^{\circ} \mathrm{C}$ & $37.35^{\circ} \mathrm{C}$ & $38.5^{\circ} \mathrm{C}$ & $40.9^{\circ} \mathrm{C}$ \\
\hline
\end{tabular}

(A) Vertical height differences

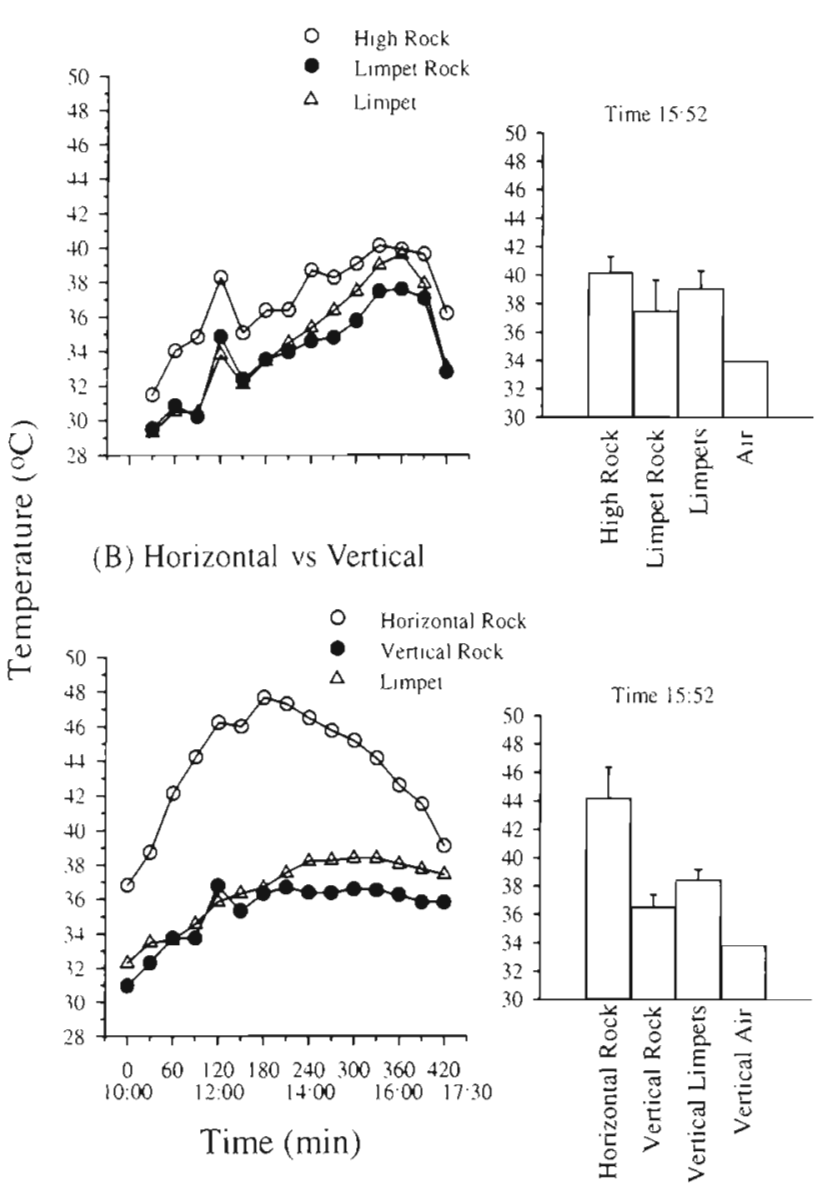

Fig. 6. Cellana grata. Comparison of habitat and limpet body temperatures between: (A) limpets in refuges (limpet, $n=6$ ) on vertical rock surfaces (limpet rock, $\mathrm{n}=3$ ) as compared to rock surfaces $25 \mathrm{~cm}$ higher (high rock, $\mathrm{n}=3$ ). (B) Limpets in refuges (limpet, $n=6$ ) on vertical rock surfaces (vertical rock, $n=3$ ) and adjacent horizontal rock surfaces (horizontal rock, $n=3$ ). Histograms represent mean (+SD) values for the time period selected for analysis shore there were numerous herbivores and an increase in cover of encrusting algae (see Williams 1993b). The vertical distribution of C. grata varied seasonally; in the cool winter months the peak density was found at 2.5 to $3.5 \mathrm{~m}$ on very exposed shores (e.g. Big Wave Bay). During the summer months the limpets moved downshore and their peak of distribution was more than $1 \mathrm{~m}$ lower than in the winter time. A lowering of vertical zonation in response to adverse physical conditions is not uncommon in mobile species (Lewis 1954, Branch 1975) and has previously been suggested for C. grata (Liu 1994). During the summer months in Hong Kong many species reduce their vertical range (e.g. Cellana toreuma, Patelloida saccharina; Williams \& Morritt unpubl. data) and many species of algae die back or are killed in the summer heat (Williams 1993a, Kaehler \& Williams unpubl.). The vertical shift in zonation is significant because Hong Kong has a tidal range of $\sim 2.5 \mathrm{~m}$ and therefore movement downshore in the summer months would bring $C$. grata into a zone of increased barnacle cover. This movement may place $C$. grata in a zone of greater competition for resources, either algae (food) or refuges to inhabit at low tide. The distribution of food resources varied along the vertical gradient of the shore. At Cape Wall the abundance of algae, as assessed by chlorophyll $a$, increased downshore whilst at the Cape Slope site it increased in an upshore direction in both winter and summer.

\section{Diurnal rhythm of behaviour}

Cellana grata is a non-homing species of limpet which forages in the field whilst awash by the waves, a pattern also exhibited by Cellana toreuma (Hirano 1979) and many species of tropical gastropod (Garrity 1984 and see review by Little 1989). As the tide rises and waves start to splash these limpets they extend their pallial tentacles and then begin to move. Movement is rapid initially, as individuals move upshore with the incoming tide. At high tide, movement slows and appears to cease until the tide starts to ebb and the limpets return to their normal shore level. Under these conditions $C$. grata can move over $1 \mathrm{~m}$ in the vertical plane during a spring tide. This behavioural rhythm is common in tropical species which may experience physical stress whilst exposed to air and intense predation pressure whilst immersed (Garrity 1984). When the shore is awash during stormy conditions, brief observations suggest that $C$. grata remains active, and $C$. toreuma has been reported to remain active for up to $18 \mathrm{~h}$ whilst awash (Hirano 1979). The 

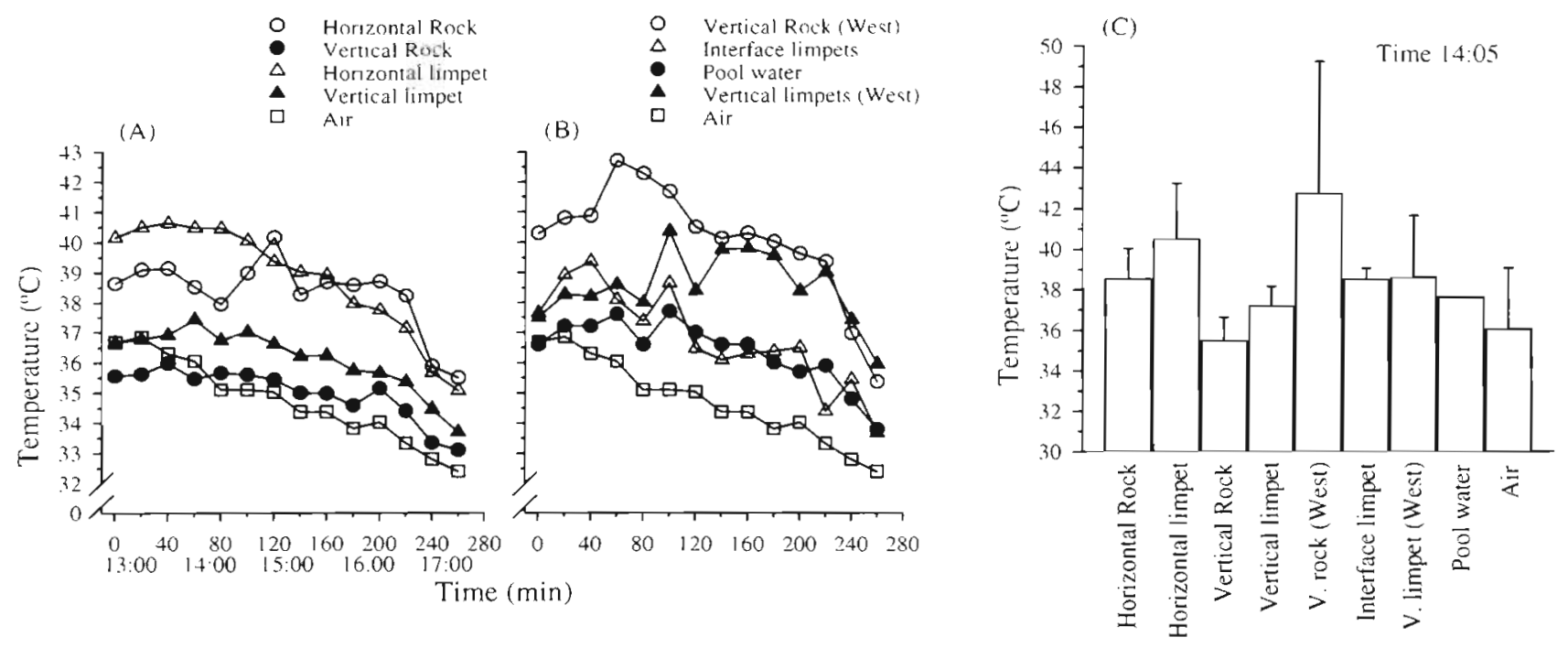

Fig. 7 Cellana grata. Comparison of limpet $(n=5)$ and habitat temperatures $(n=5)$ in $(A)$ horizontal and vertical refuges and (B) on a vertical rock face above a rock pool on 15 July 1993. (C) Histograms represent mean (+SD) values for the time period selected for analysis

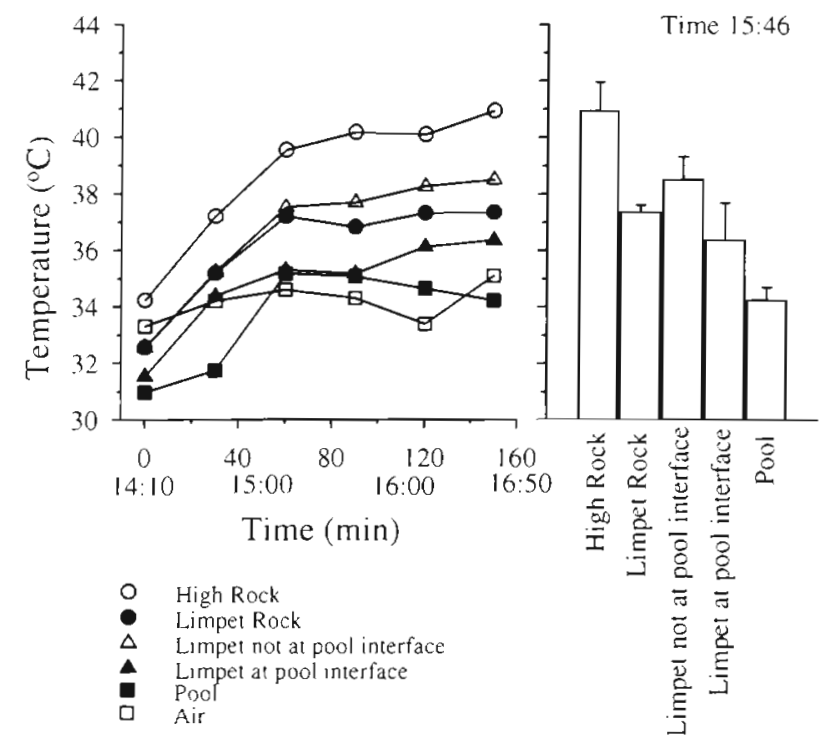

Fig. 8. Cellana grata. Limpet $(n=5)$ and habitat $(n=4)$ temperatures along a vertical wall into a rock pool. Histogram represents mean $(-5 D)$ values for the time period selected for analysis

importance of wave action as a cue to stimulate movement has been noted for a number of limpet species (e.g. Siphonaria pectinata, Thomas 1973; S. alternata, Verderber et al. 1983; Collisella limatula, Wells 1980). The reduction in 'activity' at high water has also been noted in C. toreuma (Hirano 1979) and may represent more intense feeding such as exhibited by Patella vulgata in SW Ireland (Little et al. 1988, Evans \&

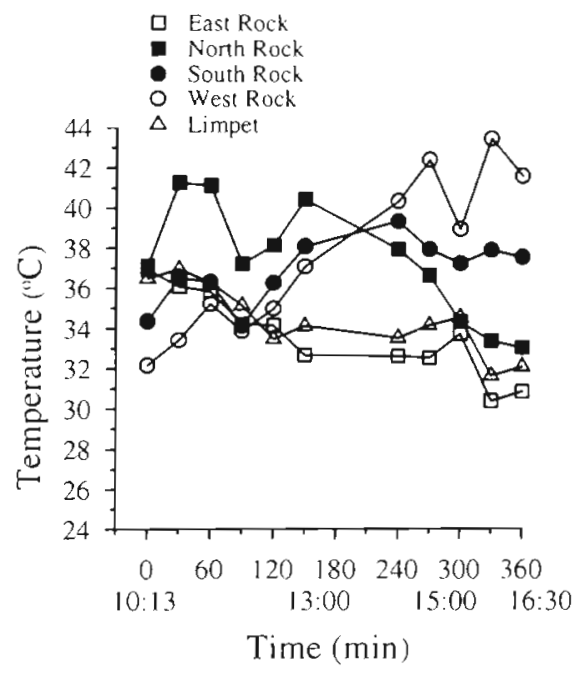

Fig. 9. Cellana grata. Habitat and limpet body temperatures for rock surfaces with different aspects. Note that limpets were only found on the easterly rock face

Williams 1991) and in $N$ Wales, UK (Chelazzi et al 1994). Movement upshore has been suggested as a means of reducing competition for food (Wolcott 1973) and on the Cape Slope this movement would also place $C$. grata in a zone of higher food abundance; although on the Cape Wall site this is not the case Wolcott (1973) hypothesized that many Acmaea spp lived high on the shore to exploit relatively unused resources and that this mode of life had an inherent risk in that individuals which moved too high on the 


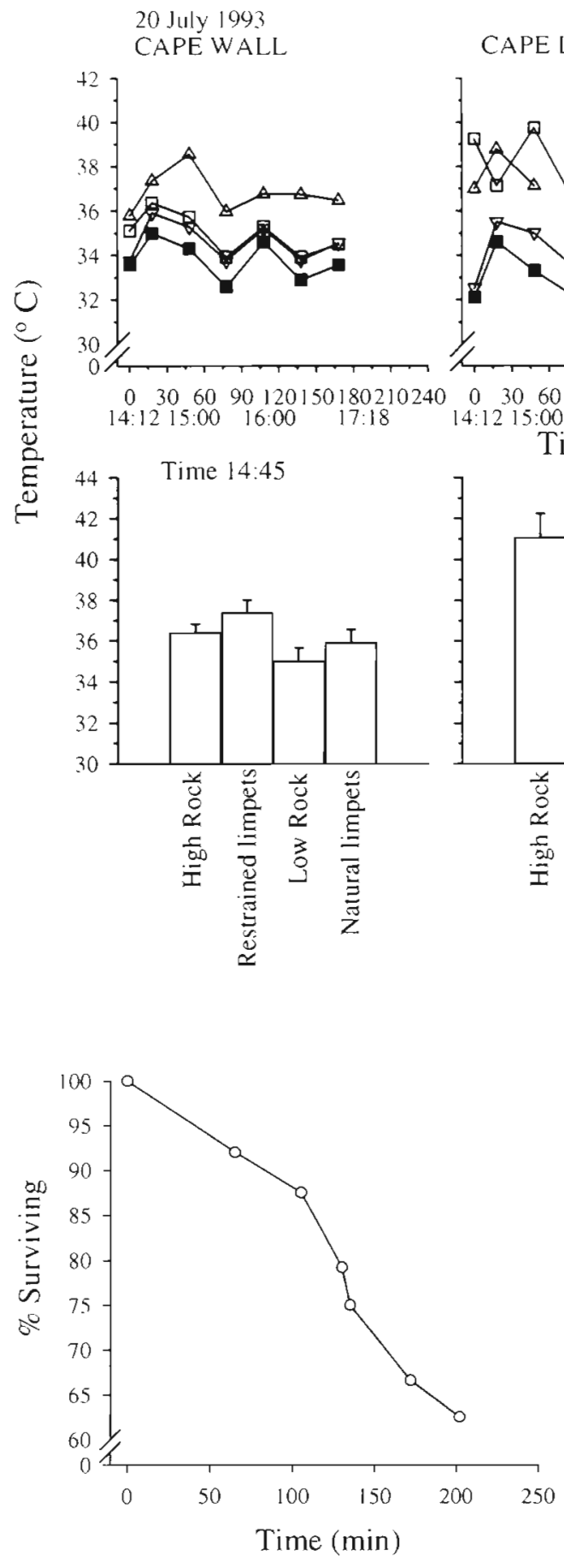

Fig. 11. Cellana grata. Mortality rate of individuals ( $n=24$ ) maintained above their normal refuge level at the Cape Ledge site on 21 July 1993

shore would face extreme physical conditions. The shuttling movement of $C$. grata up and down the shore with the tide obviates this risk while allowing access to high shore resources.
21 July 1993

CAPE LEDGE

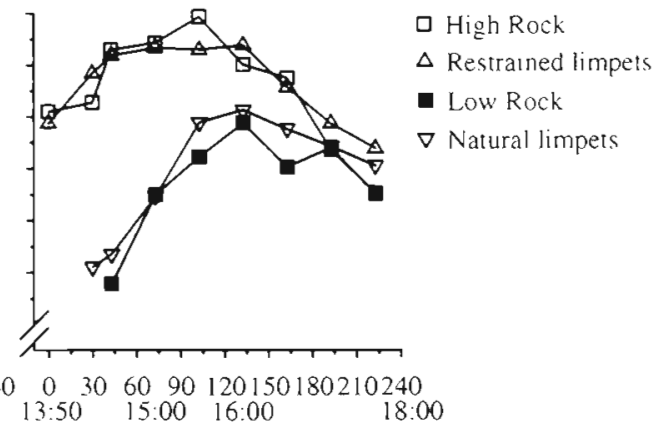

Time 15:34

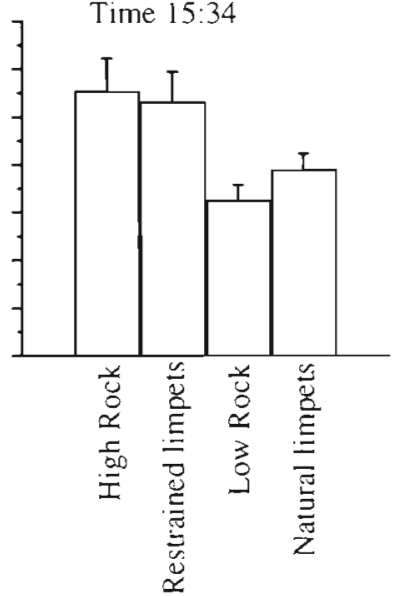

Fig. 10. Cellana grata. Limpet and habitat temperatures for individuals constrained above their normal shore level at rest and limpets allowed to return to their normal shore level. Histograms represent mean (+SD) values for the time period selected for analysis

Table 5. Cellana grata. One-way ANOVA to compare body and rock temperatures for limpets at their normal shore level $(\sim 1.75 \mathrm{~m}$ above $\mathrm{CD})$ and restrained above this normal zone $(-2.25 \mathrm{~m})$. Data for the Cape Ledge site for 20 July 1993 were not analyzed due to low sample sizes. -Significant values

Cape Wall; 20 July 1993 ( $n=5$ for limpets, 3 for rock temperatures, recordings from $14: 45$ h)

\begin{tabular}{lrrcc} 
Factor & df & MS & $F$ & $p$ \\
\hline Factor & 3 & 3.83 & 9.58 & $0.002^{\circ}$ \\
Error & 12 & 0.40 & &
\end{tabular}

SNK tests

Mid shore rock $=$ Mid shore limpet $<$ High shore rock $=$ High shore limpet $\begin{array}{llll}35.00^{\circ} \mathrm{C} & 35.90^{\circ} \mathrm{C} & 36.37^{\circ} \mathrm{C} & 37.36^{\circ} \mathrm{C}\end{array}$

Cape Ledge; 21 July 1993 ( $\mathrm{n}=7$ for limpets, 3 for rock temperatures, recordings from $15: 34 \mathrm{~h}$ )

\begin{tabular}{lrrrc} 
Factor & df & MS & $F$ & p \\
\hline Factor & 3 & 20.18 & 18.61 & $<0.001^{\circ}$ \\
Error & 16 & 1.08 & & \\
S & & & &
\end{tabular}

SNK tests

Low shore limpet $=$ Low shore rock $<$ High shore limpet $=$ High shore rock
$36.46^{\circ} \mathrm{C}$
$37.79^{\circ} \mathrm{C}$
$40.07^{\circ} \mathrm{C}$
$41.07^{\circ} \mathrm{C}$ 
Table 6. Cellana grata. Water content (\% of wet weight, mean \pm SD), dry weight and haemolymph osmolality (mean \pm SD) of restrained limpets (dead and alive) and limpets allowed to return to their normal shore level (n values). Percentage recapture rates of experimental limpets after $24 \mathrm{~h}$ are also given (total number marked in parentheses). Values below $100 \%$ are thought to represent individuals which have moved away from the experimental area as no signs of mortality (empty marked shells) were found

\begin{tabular}{|c|c|c|c|c|c|c|}
\hline & \multirow[t]{2}{*}{$n$} & \multirow{2}{*}{$\begin{array}{l}\text { Dry wt } \\
\text { (g) }\end{array}$} & \multirow{2}{*}{$\begin{array}{c}\text { Water content } \\
(\%)\end{array}$} & \multirow{2}{*}{$\begin{array}{l}\text { Haemolymph } \\
\left(\mathrm{mOsm} \mathrm{kg}^{-1}\right)\end{array}$} & \multicolumn{2}{|c|}{ Recapture } \\
\hline & & & & & 20 July & 21 July \\
\hline Restrained (dead) & (9) & $0.925 \pm 0.4$ & $35.4 \pm 6.7$ & $1831 \pm 373$ & - & - \\
\hline Restrained (alive) & (7) & $1.814 \pm 1.2$ & $42.9 \pm 4.6$ & $1463 \pm 243$ & $92 \%(38)$ & $75 \%(8)$ \\
\hline Non-restrained & (7) & $1.77 \pm 1.8$ & $42.3 \pm 9.7$ & $849 \pm 54$ & $87 \%(30)$ & $88 \%$ \\
\hline
\end{tabular}

\section{Importance of habitat and refuges}

As the tide recedes limpets retreat downshore and aggregate in specific habitats. Very few individuals settle on horizontal, unshaded rock surfaces and on hot summer days, those that do often die. In wet or damp conditions, however, limpets can survive in these habitats and are not as strongly associated with specific refuges (Williams \& Morritt unpubl. data). Aggregations of limpets in hot summer weather have been described for Patella granularis (Branch 1975) and Abe (1931) described the dispersal of such aggregations during winter storms. In the summer, Cellana grata preferentially inhabits vertical rock surfaces that are oriented away from the full heat of the sun (at Cape d'Aguilar these are east facing slopes and underhangs). Individuals are also found in clumps on horizontal or vertical surfaces in crevices or underhangs of rocks or on the interface between pools and rock surfaces. There is little clear relationship between tidal height and rock surface temperature. Horizontal rock surfaces get hotter than vertical surfaces but differences between heights are dependent on the aspect of the rock surface and the inclination of the sun (see Davies 1969, Wolcott 1973). Duration of emersion and rock aspect are probably the most important factors affecting individual survival in C. grata, as suggested by Williams (1994)

Limpet body temperatures often exceeded the rock temperatures, sometimes by as much as $2^{\circ} \mathrm{C}$. This phenomenon has also been recorded in other limpet species such as Fissurella (Lewis 1963) and Siphonaria spp. (Vermeij 1971). This may be due to the rock surface cooling evaporatively by wind action whilst the sole of the limpet's foot prevents this. The limpet may, therefore, heat up via radiation from the sun and conduction from the rock (as suggested by Davies 1970) while not experiencing the same degree of convective heat loss as the open rock surface. In all cases Cellana grata occupied areas of the shore which were cooler than adjacent habitats. Vertical refuges were the coolest, especially when compared with horizontal surfaces, and surfaces facing west heated up greatly during the latter part of the day. Limpets often clustered at rock pool interfaces and were cooler than counterparts only $15 \mathrm{~cm}$ further from the pool water. Branch (1975) has suggested that Patella granularis uses pool interfaces as a means of evaporative cooling. Pools may, however, dry out during tidal emersion and limpets can become stranded in hypersaline conditions $140 \%$

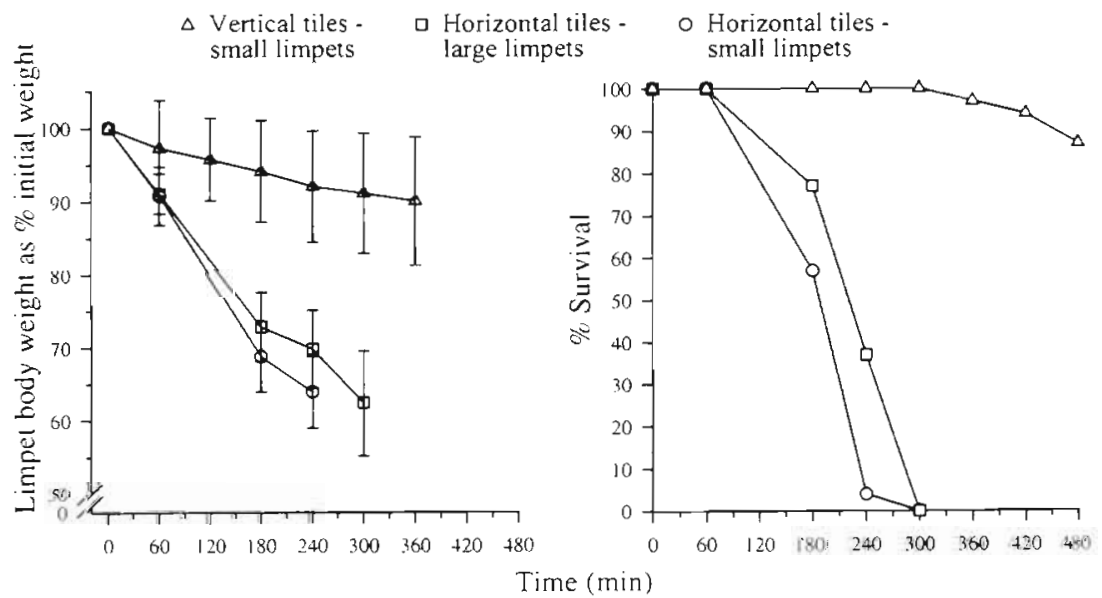

Fig. 12. Cellana grata. Water loss and survival rates of small (22 to $26 \mathrm{~mm}$ ) and large (29 to $33 \mathrm{~mm}$ ) specimens $(\mathrm{n}=30)$ maintained on horizontal substrata $(1.5$ July 1993) and small specimens in a crevice on a vertical surface $(27$ July 1993 
as compared to seawater at $28 \%$; Williams \& Morritt unpubl. data). Clearly, deeper pools offer a more predictable refuge than shallow pools which evaporate relatively quickly. Siphonaria capensis, for example, has been shown to move away or actively clamp down on its home scar when pools become hypersaline and thereby avoids subjecting the soft tissue to considerable osmotic stress (Branch \& Cherry 1985). Smallscale variation in limpet refuges, especially within aggregations of limpets, may present significant differences in physical conditions although this possibility was not considered further in the present study. Individuals of Collisella digitalis in the centre of aggregations have been shown to have reduced chloride concentrations as compared to individuals on the outside of these clumps, possibly due to the shielding effect of aggregations against desiccating winds (Gallien 1985).

Clearly there is a hierarchy in the quality of refuges into which limpets can rest, although there is no evidence either for competition or for the repeated return of individuals to the more suitable sites. Limpets appear to move randomly until they reach a specific tidal height on the ebbing tide and then settle in a suitable refuge (individuals have been shown to settle on average $-50 \mathrm{~cm}$ from their previous site on re-emersion; Williams \& Morritt unpubl. data).

Limpets which were restrained from returning to their normal level attempted to move round the cage barriers and actively tried to reach a lower position on the shore. These specimens were emersed and received direct insolation for longer and attained higher temperatures than their lower shore counterparts, and many individuals on horizontal rock surfaces died. Those on the vertical wall did not experience such extreme conditions and all these limpets survived. The haemolymph concentration of individuals which died was twice that of lower shore individuals, whilst those that survived at the high shore level also had greatly increased haemolymph osmolality compared to the lower-shore individuals. An increase in the osmolality of both haemolymph and extracorporeal water associated with increasing desiccation has been noted in many species (e.g. Acmaea limatula, Segal \& Dehnel 1962; Acmaea spp., Wolcott 1973; Siphonaria alternata, Verderber et al. 1983; S. capensis, Branch \& Cherry 1985; Collisella digitalis, Gallien 1985). With progressive emersion Cellana grata lost the majority of its mantle water after $7 \mathrm{~h}$. The concentration of this mantle water increased from $106.2 \pm$ SD $2.1 \%$ seawater $(n=3)$ at the point of emersion to $141.5 \pm 15.6 \%$ seawater ( $n=5$ ) after $6 \mathrm{~h}$ emersion. This fluid presumably acts as a buffer to desiccation stress. Limpet body fluids will also be affected by diffusion of electrolytes into the specimen as mantle fluid concentrates and water will be lost to the fluid down an osmotic gradient.
Thus, there will be a dynamic equilibrium between the 2 fluid compartments. In A. limatula, Segal \& Dehnel (1962) observed water movement from sinuses of the individual into the extravisceral space under conditions of extreme desiccation.

Water loss and death on exposed horizontal tiles was rapid in Cellana grata, especially in smaller individuals which have a higher surface area to volume ratio than their larger counterparts. More severe desiccation stress in smaller individuals is common (Collins 1979, Lowell 1984) and also a difference in rates with habitat, specifically angle of the rock (Collins 1979). C. grata on vertical tiles lost proportionally less water than those on horizontal surfaces, and although these experiments were carried out on different days temperatures were similar. Limpets in vertical refuges will therefore experience lower temperatures and will also be subjected to reduced desiccation stress. Lethal water loss in C. grata $(-30 \%)$ occurs at lower levels than those recorded for other species (Acmaea spp. 70\%, Wolcott 1973; Siphonaria theristes 70 to $75 \%$, Branch 1988; Cellana ornata $60 \%$ after $6 \mathrm{~h}$, Smith 1975) although it is similar to that recorded for Patella granularis $\left(35 \% \mathrm{LD}_{50}\right.$; Marshall \& McQuaid 1992), however, this was over a much greater time period.

\section{Other behavioural adaptations}

Cellana grata does not appear to have some of the adaptations exhibited by other gastropods to tolerate temperature and desiccation stress. It does not form a mucus sheet as an adaptation to evaporative water loss as do some species (e.g. Collisella digitalis, Wolcott 1973, Gallien 1985; Collisella scabra, Collins 1979) nor does it home to a scar which has been shown to be another adaptation to temperature stress (e.g Siphonaria; Verderber et al. 1983, Branch \& Cherry 1985). C. grata does, however, exhibit 'mushrooming' behaviour, lifting the shell to expose the foot and pallial tentacles, when stressed by high temperatures. Individuals which exhibit this response will, during continued exposure to high temperatures, eventually die (Williams \& Morritt unpubl. data). This behaviour has been recorded in other species (e.g. Siphonaria species, Vermeij 1971; Acmaea spp., Wolcott 1973; Collisella pelta, Lowell 1984) and has been suggested to function in evaporative cooling (Segal \& Dehnel 1962) by exposing extravisceral water to air, although there is no evidence to support this. Perhaps tropical limpets, including C. grata, reach a certain threshold where the need for cooling 'overrides' potential desiccation and this leads to the initiation of a 'mushrooming' response, although Wolcott (1973) argues that 
under desiccating conditions water conservation is often of more importance than thermoregulation. Elevated temperatures are not only associated with desiccation effects and associated osmotic problems, but also adversely affect other physiological processes such as impedance of $\mathrm{CO}_{2}$ excretion and/or $\mathrm{O}_{2}$ diffusion (Marshall \& McQuaid 1992) which are integrally linked to water availability.

Cellana grata relies on foraging whilst awash and then returning to a suitable refuge to sit out the low water emersion. C. grata is therefore an opportunist forager whose behaviour is strongly controlled by physical factors. Those individuals that either do not return low enough on the shore, or who select suboptimal refuges, experience higher temperatures, lose water rapidly and can die. On calm, hot, summer days refuges which are acceptable under normal conditions can reach lethal temperatures. Such stochastic events can result in mass mortalities of limpets (e.g. Rottnest Island, Australia, Kohn 1993; Cape d'Aguilar, Hong Kong, July 1990 and April 1994, Williams pers. obs.). This can account for great between-site variation in limpet size and abundance and can have a large influence on the structure and function of intertidal assemblages (see Underwood et al. 1983). Clearly selection favours a strong behavioural rhythm entrained by wave splash and retreat into safe refuge sites on emersion. Such a rhythm will have implications on the effect of $C$. grata on the high-shore assemblage because foraging time and range will be dictated by a combination of tides, wave action and refuge availability which are variable in space and time.

Acknowledgements. Many thanks to the people who provided support, Dr B. W. Darvell (Prince Phillip Hospital, Hong Kong University); Prof. Wong (Chinese University of Hong Kong) and Dr May Yipp (Hong Kong Polytechnic). Field work assistance was cheerfully supplied by Sven Kaehler, Robin Kennish, Mak Yiu Ming, Ben, Yim Po Man (Hong Kong University) and Dr Mark Davies (Sunderland University). Many thanks to Kelly, Lau Lai Yip who drew the figures. Support for D.M. was provided by a Hong Kong University Visiting Lectureship, and travel grants from the Royal Society and the AFRC Wain Travel fund. Equipment and consumables were supported by a Hong Kong University Research Grant to G.A.W. The manuscript was improved by comment from Dr David Dudgeon (Hong Kong University), Prof Brian McMahon (Calgary University) and Dr Colin Little (Bristol University).

\section{LITERATURE CITED}

Abe $N$ (1931) Ecological observations in Acmaea dorsuosa Gould. Sci Rep Tohoku Imp Univ (4) 6:403-427

Branch GM (1975) Mechanisms reducing intraspecific competition in Patella spp. migration, differentiation and territorial behaviour. J Anim Ecol 44:575-600

Branch GM (1981) The biology of limpets: physical factors, energy flow and ecological interactions. Oceanogr mar Biol A Rev 19:235-379
Branch GM (1988) Activity rhythms in Siphonaria thersites. In: Chelazzi $G$, Vannini $M$ (eds) Behavioural adaptations to intertidal life. NATO ASI Series, Plenum Press, London, p $27-44$

Branch GM, Cherry MI (1985) Activity patterns of the pulmonate limpet Siphonaria capensis Q. \& G. as an adaptation to osmotic stress, predation and wave action. J exp mar Biol Ecol 87:153-168

Chelazzi G, Santini G, Parpagnoli D, Santina PD (1994) Coupling motographic and sonographic recording to assess foraging behaviour of Patella vulgata. J mollusc Stud 60: $123-128$

Collins LS (1979) Abundance, substrate angle, and desiccation resistance in two sympatric species of limpets. Veliger 19:199-205

Connell JH (1961) Effects of competition, predation by Thais lapillus, and other factors on natural populations of the barnacle Balanus balanoides. Ecol Monogr 31:61-104

Davies PS (1969) Physılogical ecology of Patella. III. Desiccation effects. J mar biol Ass UK 49:291-304

Davies PS (1970) Physiological ecology of Patella. IV. Environmental and limpet body temperatures. J mar biol Ass UK 50:1069-1077

Evans MR, Williams GA (1991) Time partitioning of foraging in the limpet Patella vulgata. J Anim Ecol 60:563-575

Frank PW (1965) The biodemography of an intertidal snail population. Ecology 46:831-844

Gallien WB (1985) The effects of aggregations on water loss in Collisella digitalis. Veliger 28:14-17

Garrity SD (1984) Some adaptations of gastropods to physical stress on a tropical rocky shore. Ecology 65:559-574

Garrity SD, Levings SC (1981) A predator-prey interaction between two physically and biologically constrained tropical rocky shore gastropods: direct, indirect and community effects. Ecol Monogr 51:267-286

Hawkins SJ, Hartnoll RG (1985) Factors determining the upper limits of intertidal canopy-forming algae. Mar Ecol Prog Ser 20:265-271

Hill AS, Hawkins SJ (1990) An investigation of methods for sampling microbial films on rocky shores. J mar biol Ass UK 70:77-88

Hirano Y (1979) Studies on activity pattern of the patellid limpet Cellana toreuma (Reeve). J exp mar Biol Ecol 40: 137-148

Kohn AJ (1993) Episodic mortality of limpets on a shore platform at Rottnest Island, Western Australia. In: Wells F, Walker D, Kurkman H, Letterbridge R (eds) Fifth International Marine Biology Workshop: The Marine Flora and Fauna of Rottnest Island, Western Australia. Western Australia Museum, p $1-12$

Leviten PJ, Kohn AJ (1980) Microhabitat resource use, activity patterns, and episodic catastrophe: Conus on tropical intertidal reef rock benches. Ecol Monogr 50:55-75

Lewis JB (1963) Environmental and tissue temperatures of some tropical intertidal marine animals. Biol Bull 124: 277-284

Lewis JR (1954) Observations on a high-level population of limpets. J Anim Ecol 23:85-100

Little C (1989) Factors governing patterns of foraging activity in littoral marine herbivorous molluscs. J mollusc Stud 55: 273-284

Little C, Stirling P (1985) Patterns of foraging activity in the limpet Patella vulgata L. - a preliminary study. J exp mar Biol Ecol 89:283-296

Little C, Williams GA, Morritt D, Perrins JM, Stirling P (1988) Foraging behaviour of Patella vulgata L. in an Irish sealough. J exp mar Biol Ecol 120:1-21 
Liu JH (1994) The ecology of the Hong Kong limpets Cellana grata (Gould, 1859) and Patelloida pygmea (Dunker, 1860 ): distribution and population dynamics. J mollusc Stud 59:55-67

Liu JH, Morton BS (1994) The temperature tolerance of Tetraclita squamosa (Crustacea: Cirripedia) and Septifer virgatus (Bivalvia: Mytilidae) on a sub-tropical rocky shore in Hong Kong. J Zool Lond 234:325-339

Lowell RB (1984) Desiccation of intertidal limpets: effects of shell size, fit to substratum, and shape. J exp mar Biol Ecol 77:197-207

Marshall DJ, McQuaid CD (1992) Comparative aerial metabolism and water relations of the intertidal limpets Patella granularis L. (Mollusca: Prosobranchia) and Siphonaria oculus Kr. (Mollusca: Pulmonata). Physiol Zool 65: 1040-1056

McMahon RF (1990) Thermal tolerance, evaporative water loss, air-water oxygen consumption and zonation of intertidal prosobranchs: a new synthesis. Hydrobiologia 193: $241-260$

Moore HB (1972) Aspects of stress in the tropical marine environment. Adv mar Biol 10:217-269

Raimondi PT (1990) Patterns, mechanisms, consequences of variability in settlement and recruitment of an intertidal barnacle. Ecol Monogr 60:283-309

Schonbeck M, Norton TA (1978) Factors controlling the upper limits of fucoid algae on the shore. J exp mar Biol Ecol 31:303-313

Segal E, Dehnel PA (1962) Osmotic behaviour in an intertidal limpet, Acmaea limatula. Biol Bull 122:417-430

Smith SL (1975) Physiological ecology of the limpet Cellana ornata (Dillwyn). NZ I mar Freshwat Res 9:395-402

Thomas RF (1973) Homing behaviour and movement rhythms

This article was submitted to the editor in the pulmonate limpet, Siphonaria pectinata Linnaeus Proc malac Soc Lond 40:303-311

Underwood AJ, Denley EJ, Moran MJ (1983) Experimental analyses of the structure and dynamics of mid-shore rocky intertidal communities in New South Wales. Oecologia 56:202-219

Verderber GW, Cook SB, Cook CB (1983) The role of the home scar in reducing water loss during aerial exposure of the pulmonate limpet, Siphonaria alternata (Say). Veliger $25: 235-243$

Vermeij GJ (1971) Temperature relationships of some tropical Pacific intertidal gastropods. Mar Biol 10:308-314

Wells RA (1980) Activity pattern as a mechanism of predator avoidance in two species of acmaeid limpet. $\mathrm{J}$ exp mar Biol Ecol 48:151-168

Williams GA (1993a) Seasonal variation in algal species richness and abundance in the presence of molluscan herbivores on a tropical rocky shore. J exp mar Biol Ecol 167 : $261-275$

Williams GA (1993b) The relationship between herbivorous molluscs and algae on moderately exposed Hong Kong shores. In: Morton BS (ed) The marine biology of the South China Sea. Hong Kong University Press, Hong Kong, p 459-470

Williams GA (1994) The relationship between shade and molluscan grazing in structuring communities on a moderately-exposed tropical rocky shore. J exp mar Biol Ecol 178:79-95

Wolcott TG (1973) Physiological ecology and intertidal zonation in limpets (Acmaea) a critical look at 'limiting factors' Biol Bull 145:389-422

Zar JH (1984) Biostatistical analysis, 2nd edn. Prentice-Hall, Inc, Englewood Cliffs

Manuscript first received: December 8, 1994

Revised version accepted: March 15, 1995 